\title{
Analisis Faktor Kepuasan Pengguna Layanan Website SKCK Online Menggunakan Metode End User Computing Satisfaction (EUCS) (Studi Kasus: Banyuwangi)
}

\author{
${ }^{1}$ Yanuar Nurdiansyah, Eka Putri Agustini Wulandari², Diah Ayu Retnani Wulandari ${ }^{3}$ \\ 1,2,3 Fakultas Ilmu Komputer, Universitas Jember \\ yanuar_pssi@unej.ac, ideputri054@gmail.com,diah.retnaniw@gmail.com
}

\begin{abstract}
One of the main duties of the police is to provide services to the community, namely the preparation of Police Record Certificate (SKCK). Making SKCK based online to facilitate the community in making SKCK. But there are some online SKCK users, there are still many problems that arise and criticism of online SKCK. Therefore it is necessary to measure the level of satisfaction and analyze the factors that affect user satisfaction with online SKCK. This study uses the End User Computing Satisfaction (EUCS) method. This type of research is quantitative by distributing questionnaires to SKCK registrants in the Banyuwangi area. Data analysis was carried out by using valid test, reliable test, descriptive statistical test, F test and $\mathrm{T}$ test using SPSS 22. The results of the descriptive test with the Likert scale in order of the largest, namely the content variable with a percentage of $85.4 \%$, are included in the Very Satisfied category, the $80.4 \%$ timeliness variable is included in the Very Satisfied category, the $75.8 \%$ ease of use variable is included in the Satisfied category, the $73.2 \%$ format variable is included in the Satisfied category and $67.5 \%$ accuracy variable is included in the Satisfied category.
\end{abstract}

Keyword: EUCS, satisfaction, user, website

\section{Pendahuluan}

Menurut Undang-Undang Republik Indonesia pasal 13 Nomor 2 tahun 2002 tentang tugas pokok Kepolisian yaitu memberikan perlindungan, pengayoman, dan pelayanan kepada masyarakat [1]. Salah satu pelayanan kepada masyarakat yaitu pembuatan Surat Keterangan Catatan Kepolisian (SKCK). Surat Keterangan Catatan Kepolisian atau SKCK adalah surat keterangan resmi yang diterbitkan oleh POLRI melalui fungsi Intelkam kepada seseorang pemohon/warga masyarakat untuk memenuhi permohonan dari yang bersangkutan atau suatu keperluan karena adanya ketentuan yang mempersyaratkan, berdasarkan hasil penelitian biodata dan catatan Kepolisian yang ada tentang orang tersebut (Vide Peraturan Kapolri Nomor 18 Tahun 2014). SKCK memiliki masa berlaku sampai dengan 6 (enam) bulan sejak tanggal diterbitkan. Jika telah melewati masa berlaku dan bila dirasa perlu, SKCK dapat diperpanjang oleh yang bersangkutan.

Dalam meningkatkan kualitas pelayanan Kepolisian meluncurkan inovasi baru program SKCK online pada awal September 2016 oleh Kapolri Jendral (Pol) Tito Karnavian [1]. Program ini berbasis IT sehingga mempermudah dan pembuatan SKCK online dapat mengakses dan mendaftar secara online tanpa meminta surat pengantar atau keterangan dari RT, RW, Kelurahan/Desa setempat, jika sebelumnya pemrosesannya dilakukan secara manual sehingga membutuhkan waktu berhari-hari yang akan membutuhkan waktu yang banyak. Akan tetapi dari keberhasilan para stakeholder terkait program pembuatan SKCK Online ini tergolong baru sehingga program ini masih belum bisa berjalan secara optimal, karena masih terdapat hambatan atau kendala dalam pelaksanaanya. Berdasarkan hasil wawancara pada salah satu responden terdapat beberapa permasalahan seperti banyaknya kritik kurang baik dari pendaftar karena beberapa penginputan data tidak berfungsi atau mengalami loading lama dan kembali ke tahap awal penginputan data sehingga mengharuskan pendaftar untuk mengisi data mulai dari awal lagi, pendaftar masih kebingungan untuk mengisi data yang diinputkan. Ketidakjelasan laporan setelah proses input data untuk mencetak kode registrasi, kurangnya minat dari masyarakat terutama kalangan orang - orang yang awam akan teknologi. Berdasarkan beberapa permasalahan yang terjadi, maka perlu dilakukan pengukuran tingkat kepuasan pengguna dan menganalisa faktor yang mempengaruhi kepuasan pengguna terhadap website SKCK online sehingga dapat dipertahankan dan ditingkatkan kualitas layanan website SKCK online menggunakan metode EUCS yang di kembangkan oleh Doll dan Torkzadeh pada 1988. Metode End User Computing Satisfaction adalah metode untuk mengukur 
kepuasan dari pengguna suatu sistem informasi. Metode ini mempunyai 5 variabel yaitu content, accuracy, format ease of use, Timeliness [2].

Berdasarkan latar belakang di atas, pada penelitian ini akan dilakukan penelitian tentang analisis faktor yang mempengaruhi tingkat kepuasan pengguna website SKCK Online dengan metode End User Computing Satisfaction (EUCS). Dalam hal ini terdapat variabel yang diukur yaitu: content, accuracy, format, ease of use, Timeliness. Kelima variabel tersebutjuga menjadi variabel independent dan kepuasan pengguna menjadi variabel dependen. Objek penelitian ini adalah pengguna layanan website SKCK Online di Polres Banyuwangi. Hasil dari penelitian ini akan menemukan faktor yang berpengaruh positif dan signifikan terhadap kepuasan pengguna layanan website SKCK Online. Jenis penelitian ini adalah penelitian kuantitatif. Data penelitian didapatkan dengan cara menyebarkan kuesioner kepada pengguna layanan website SKCK Online di Polres Banyuwangi.

\section{Metodologi Penelitian}

\subsection{Objek dan Lokasi Penelitian}

Objek penelitian merupakan layanan website SKCK online dan data didapat dari responden dimana responden disini merupakan user atau pengguna layanan website SKCK online di daerah Banyuwangi.

\subsection{Tahapan Penelitian}

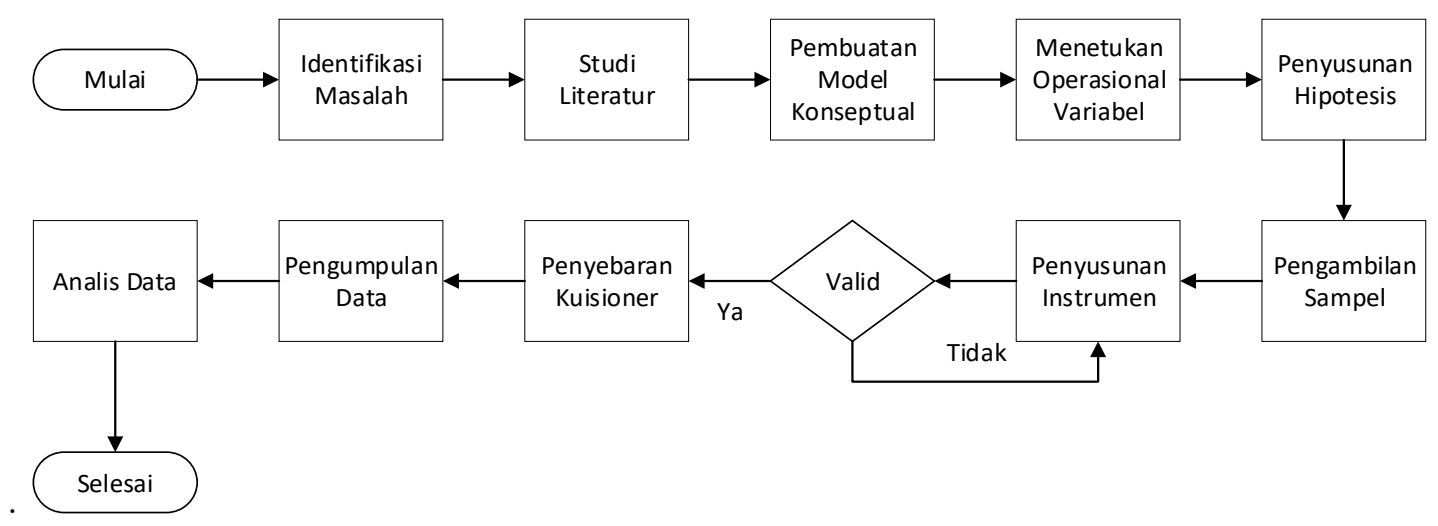

Gambar 1. Tahapan Penelitian

\section{Hasil dan Pembahasan}

\subsection{Teknik Pengumpulan Data}

Pengambilan sampel penelitian ini menggunakan teknik simple random sampling, merupakan pengambilan anggota sampel dari populasi dilakukan secara acak tanpa memperhatikan strata yang ada dalam populasi itu. Teknik ini termasuk kedalam Teknik pengambilan sampel Probability sampling yang memberikan eluang yang sama setiap unsur (anggota) populasi untuk dipilih menjadi anggota sampel. Hasil wawancara pada pihak terkait di Polres Banyuwangi pada tanggal 29 April 2019 diperoleh jumlah populasi pendaftar SKCK Online dari bulan Januari 2018 sampai Maret 2019 yang berjumlah 30.215 orang.

\subsection{Instrumen Penelitian}

End User Computing Satisfaction (EUCS) adalah metode untuk mengukur tingkat kepuasan dari pengguna suatu sistem aplikasi dengan membandingkan antara harapan dan kenyataan dari sebuah sistem informasi. Definisi End User Computing Satisfaction dari sebuah sistem informasi adalah evaluasi secara keseluruhan dari para pengguna sistem informasi yang berdasarkan pengalaman mereka dalam menggunakan sistem tersebut [2]. Model evaluasi yang dikembangkan oleh Doll \& Torkzadeh ini lebih menekankan kepuasan (satisfaction) pengguna akhir terhadap aspek teknologi, dengan menilai isi, keakuratan, bentuk, waktu dan kemudahan pengguna dari sistem [3]. 


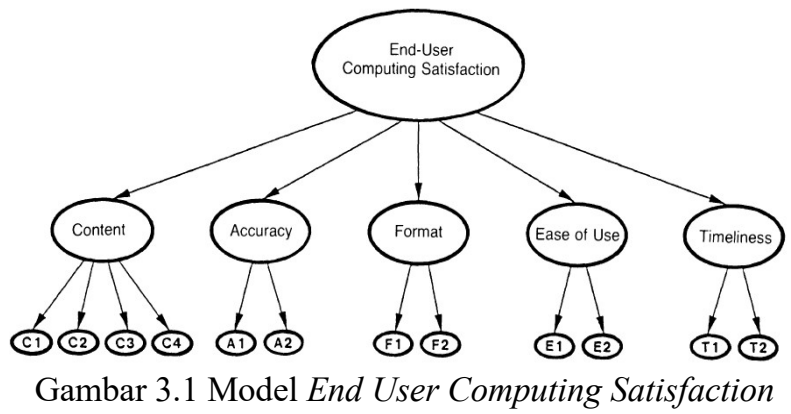

\subsection{Uji Instrumen}

\subsubsection{Uji Validias}

Uji validitas pada studi kasus penelitian ini dilakukan menggunakan tools SPSS (Statistical Package for the Social Sciences). Dengan menggunakan significant 95\% (0.95) dan error 5\% (0.05) yang artinya tingkat akurasi dari instrumen penelitian ini mencapai 95\% dan error hingga 5\%. Pengujian dilakukan dengan menggunakan korelasi bivariat, dikatakan suatu model valid jika nilai $r$ hitung $>r$ tabel pada $\alpha=5 \%$. Hasil uji validitas yang dinyatakan tidak valid dapat diatas dengan cara memperbaiki pertanyaan-pertanyaan yang tidak valid dan membagikan ulang instrumen tersebut kepada responden dan diuji kembali. Jika setelah membagikan ulang dan diuji variabel yang tidak valid masih dinyatakan tidak valid makan perlu dilakukan drop atau membuang item-item kuisioner yang tidak valid tersebut. Hasil Pada Penelitian ini yaitu VALID

\subsubsection{Uji Reliabilitas}

Uji reabilitas di penelitian ini dilakukan menggunakan SPSS 16, dengan menggunakan significant 95\% (0.95) dan error 5\% (0.05) yang artinya tingkat akurasi dari instrument penelitian ini mencapai 95\% dan error hingga 5\%. Metode yang digunakan untuk mengukur reabilitas kuisioner adalah dengan metode Cronbach's Alpha. Uji realibilitas ini dikatakan reliabel jika suatu nilai Cronbach's Alpha > 0,6 [4]. Hasil uji reliabilitas yang dinyatakan tidak reliabel dapat diatasi dengan cara memperbaiki pertanyaan-pertanyaan yang tidak reliabel dan membagikan ulang instrumen tersebut kepada responden dan diuji kembali. Jika setelah membagikan ulang dan diuji variabel yang tidak reliabel masih dinyatakan tidak reliabel maka perlu dilakukan drop atau membuang item-item kuisioner yang tidak reliabel tersebut. Dari uji reabilitas pada seluruh variabel mencukupi syarat yaitu suatu instrumen dapat dinyatakan reliabel jika nilai Cronbach's Alpha $>0,6$. Didapat nilai Cronbach's Alpha diatas minimum 0,6 sehingga keseluruhan variabel atau domain bisa dinyatakan RELIABEL [5].

\subsection{Analisis Data}

\subsubsection{Uji F}

Uji $\mathrm{F}$ dilakukan untuk mengetahui variabel bebas $(\mathrm{X})$ berpengaruh signifikansi secara simultan (bersama) terhadap variabel terikat (Y). Variabel bebas pada penelitian ini yaitu Content (X1), Accuracy (X2), Format (X3), Ease of Use (X4), dan Timeliness (X5) yang akan diuji secara simultan (bersama) terhadap variabel terikat User Satifaction (Y) sehingga akan diketahui bahwa model regresi yang telah dibuat baik signifikan atau tidak signifikan. Berdasarkan hasil dari SPSS, model ini memiliki nilai signifikansi yang diperoleh nilai f hitung sebesar 6,052 $>$ f tabel sebesar 2,23719 dan nilai signifikasi sebesar $0,000<0,05$, yang berarti pada uji f dihasilkan variabel bebas (content, accuracy, format, ease of use dan Timeliness) secara simultan (bersama) berpengaruh terhadap variabel terikat yaitu kepuasan pengguna (user satisfaction).

\section{Tabel 3.1 Hasil Uji F}

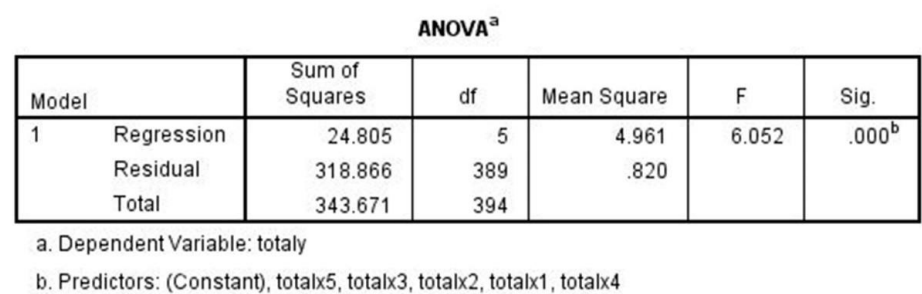

\subsubsection{Uji T}

Uji T dalam penelitian ini dilakukan untuk menguji pengaruh setiap variabel bebas terhadap variabel terikat. Variabel bebas pada penelitian ini yaitu Content (X1), Accuracy (X2), Format (X3), Ease of Use (X4), dan Timeliness (X5), sedangkan variabel terikatnya yaitu User Satifaction (Y). Menentukan terlebih dulu nilai $\mathrm{t}$ tabel yang nantinya akan dibandingkan dengan nilai $\mathrm{t}$ hitung. Nilai $\mathrm{t}$ tabel dapat ditentungan menggunakan distribusi t atau menggunakan fungsi "=TINV $(\alpha ; \mathrm{df})$ " pada Microsoft excel. Simbol $\alpha$ melambangkan 
probabilitas yang digunakan, pada penelitian ini probabilas yang digunakan sebesar 0,05 . Nilai df didapat dari banyaknya sampel dikurangi 2 yaitu 393, sehingga menggunakan fungsi " $=\operatorname{TINV}(0,05 ; 393)$ " menghasilkan nilai t tabel sebesar 1,966019 .

Tabel 3.2 Hasil Uji T

Coefficients $^{\mathrm{a}}$

\begin{tabular}{|c|c|c|c|c|c|c|}
\hline \multirow[b]{2}{*}{ Mode } & & \multicolumn{2}{|c|}{ Unstandardized Coefficients } & \multirow{2}{*}{$\begin{array}{c}\text { Standardized } \\
\text { Coefficients } \\
\text { Beta }\end{array}$} & \multirow[b]{2}{*}{$\mathrm{t}$} & \multirow[b]{2}{*}{ Sig. } \\
\hline & & $B$ & Std. Error & & & \\
\hline \multirow[t]{6}{*}{1} & (Constant) & 5.073 & .505 & & 10.041 & .000 \\
\hline & totalx1 & .073 & .027 & 133 & 2.680 & .008 \\
\hline & totalx 2 & .072 & .035 & 102 & 2.080 & .038 \\
\hline & total $\times 3$ & .070 & .030 & .116 & 2.326 & .021 \\
\hline & totalx 4 & .082 & .036 & .113 & 2.300 & .022 \\
\hline & totalx 5 & -.088 & .037 & -.118 & -2.379 & .018 \\
\hline
\end{tabular}

Disimpulkan Hasil Analisa data pada uji f dan uji t dapat dijadikan sebagai penarikan kesimpulan pada penelitian ini, bahwa semua variabel mempengaruhi variabel terikat. Ke 6 variabel (Content, Accuracy, Format, Ease of Use dan Timeliness) mempunya H0 tidak berpengaruh postif dan signifikan terhadap kepuasan pengguna (EUCS) dan Ha berpengaruh positif dan signifikan terhadap kepuasan pengguna (EUCS).

Gambar 3.3 Hasil Uji Hipotesis

\begin{tabular}{clc}
\hline & \multicolumn{1}{c}{ Hipotesis } & Keterangan \\
\hline H1 & $\begin{array}{l}\text { Variabel Content berpengaruh positif dan signifikan } \\
\text { terhadap kepuasan pengguna akhir web SKCK Online }\end{array}$ & DITERIMA \\
\hline H2 & $\begin{array}{l}\text { Variabel Format berpengaruh positif dan signifikan } \\
\text { terhadap kepuasan pengguna akhir web SKCK Online }\end{array}$ & DITERIMA \\
\hline H4 & $\begin{array}{l}\text { Variabel Format berpengaruh positif dan signifikan } \\
\text { terhadap kepuasan pengguna akhir web SKCK Online }\end{array}$ & DITERIMA \\
& $\begin{array}{l}\text { Variabel Ease of Use berpengaruh positif dan signifikan } \\
\text { terhadap kepuasan pengguna akhir web SKCK Online }\end{array}$ & DITERIMA \\
\hline H5 & $\begin{array}{l}\text { Variabel Timeliness berpengaruh negatif dan signifikan } \\
\text { terhadap kepuasan pengguna akhir web SKCK Online }\end{array}$ & DITOLAK \\
\hline
\end{tabular}

\subsection{Analisis Deskriptif}

\begin{tabular}{|c|l|l|l|}
\hline No & Variabel & Persentase & Keterangan \\
\hline 1 & Content & $85,4 \%$ & Sangat Puas \\
\hline 2 & Accuracy & $67,5 \%$ & Puas \\
\hline 3 & Format & $73,2 \%$ & Puas \\
\hline 4 & Ease of Use & $75,8 \%$ & Sangat Puas \\
\hline 5 & Timeliness & $80,4 \%$ & Sangat Puas \\
\hline
\end{tabular}

\section{Kesimpulan}

Berdasarkan hasil penelitian yang telah dilakukan pada layanan website SKCK online maka dapat disimpulkan bahwa:

1. Hasil analisis yang telah dilakukan didapatkan faktor content, faktor accuracy, faktor format, dan faktor ease of use berpengaruh positif dan signifikan terhadap kepuasan pengguna layanan website SKCK online dan signifikan terhadap kepuasan layanan website SKCK online.

2. Mengukur kepuasan pengguna website SKCK online diperoleh hasil analisis deskriptif dengan skala likert secara terurut dari yang terbesar yaitu variabel content dengan persentase $85,4 \%$ termasuk kedalam kategori Sangat Puas, variabel timeliness dengan persentase $80,4 \%$ termasuk kedalam kategori Sangat Puas, variabel ease of use dengan persentase $75,8 \%$ termasuk kedalam kategori Sangat Puas, variabel format dengan persentase 73,2\% termasuk kedalam kategori Puas dan variabel accuracy dengan persentase 67,5\% dan termasuk kedalam kategori Puas. Hasil tersebut menjelaskan bahwa variabel accuracy merupakan variabel yang sangat perlu diperbaiki karena memiliki nilai persentase yang kecil terhadap variabel accuracy meskipun masuk range kategori puas, variabel content dan variabel timeliness merupakan variabel yang perlu dipertahankan karena mencapai persentase yang besar dan masuk range kategori sangat puas sedangkan variabel format dan variabel ease of use merupakan variabel yang sesuai dengan harapan pengguna karena memiliki nilai persentase dengan range kategori puas ditinjau dari hasil penilaian kuesioner pengguna layanan website SKCK online. 
3. Rekomendasi yang diberikan berdasarkan dari hasil analisis adalah sebagai berikut:

a. Variabel content

Variabel content pada penelitian ini diharapkan Polres Banyuwangi tetap menjaga dan meningkatkan variabel content. Variabel content terdiri dari konten pada website sudah tepat dan sesuai dengan kebutuhan, konten pada website sudah memenuhi kebutuhan pengguna. Website telah memberikan laporan yang tepat sesuai dengan kebutuhan pengguna, dan konten pada website telah memberikan informasi yang cukup, pada website SKCK online dapat dilihat dari isi data diri, hub. keluarga, dll.

b. Variabel accuracy

Variabel accuracy pada penelitian ini diharapkan Polres Banyuwangi tetap menjaga dan meningkatkan variabel accuracy. Variabel accuracy yang terdiri dari output dari aplikasi sudah akurat, dan responden merasa puas dengan keakuratan output pada website, pada website SKCK online dapat dilihat dari laporan pada saat submit data diri, hub. keluarga, dll.

c. Variabel format

Variabel format pada penelitian ini diharapkan Polres Banyuwangi tetap menjaga dan meningkatkan variabel format. Variabel format yang terdiri dari tampilan atau format pada website telah disajikan bermanfaat, dan informasi/konten yang disajikan website sudah jelas. Pada website SKCK online dapat dilihat dari tampilan awal, tampilan saat mengisi data diri, tampilan saat selesai submit data diri.

d. Variabel ease of use

Variabel ease of use pada penelitian ini diharapkan Polres Banyuwangi tetap menjaga dan meningkatkan variabel timeliness. Variabel timeliness yang terdiri dari informasi yang dibutuhkan responden pada website didapatkan langsung, website memberikan informasi terkini, pada website SKCK online dapat dilihat dari saat pengguna membutuhkan data informasi persyaratan dapat ditampilkan langsung, saat pengguna membutuhkan tagihan layanan website SKCK online dapat dtampilkan langsung.

e. Variabel timeliness

Variabel timeliness pada penelitian ini diharapkan Polres Banyuwangi tetap menjaga dan meningkatkan variabel timeliness. Variabel timeliness yang terdiri dari informasi yang dibutuhkan responden pada website didapatkan langsung, website memberikan informasi terkini, pada website SKCK online dapat dilihat dari saat pengguna membutuhkan data informasi persyaratan dapat ditampilkan langsung, saat pengguna membutuhkan tagihan layanan website SKCK online dapat dtampilkan langsung.

5. Saran

Saran yang diberikan peneliti untuk penelitian selanjutnya yaitu:

1. Penelitian dengan topik yang sama tentang analisis kepuasan pengguna dengan objek dan studi kasus yang sama tetapi metode yang berbeda sehingga dapat menjadi bahan pembanding, Seperti menggunakan PIECES framework karena pada penelitian dengan metode EUCS berfokus pada kepuasan pengguna, sedangkan penelitian dengan PIECES framework berfokus pada tingkat Kepuasan, juga variabel PIECES berbeda dengan EUCS.

2. Peneliti lain yang akan mengembangkan penelitian dengan metode yang sama yaitu EUCS dapat menambahkan banyak indikator atau pernyataan pada variabel yang ada agar dapat dihasilkan data yang lebih baik. Misalnya pada variabel Kepuasan pengguna dapat diberikan indikator tentang kepuasan pengguna tiap variabel independent (content, accuracy, format, ease of use, dan timeliness).

\section{Daftar Pustaka}

[1] Fauzyiah, S. (2017). INOVASI LAYANAN SURAT KETERANGAN CATATAN KEPOLISIAN (SKCK) ONLINE DI POLRESTA SIDOARJO. Universitas Negeri Surabaya.

[2] Doll, W. J., \& Torkzadeh, G. (1988). The Measurement of End-User Computing Satisfaction End-User Satisfaction The Measurement of End-User Computing Satisfaction Professor of MIS and Strategic Management The University of Toledo Gholamreza Torkzadeh Assistant Professor of Information Systems.

[3] Dalimunthe, N., \& Ismiati, C. (2016). Analisis Tingkat Kepuasan Pengguna Online Public Access Catalog Dengan Metode EUCS (Studi Kasus: Perpustakaan UIN SUSKA Riau). Jurnal Rekayasa dan Manajemen Sistem Informasi, Vol.2, No.1, 71-75.

[4] Ghozali, I. (2012). Aplikasi Analisis Multivariate Dengan Program IBM SPSS. Semarang: Universitas Diponegoro.

[5] A Budi, W. P. (2006). Reabilitas dan Validitas Konstruk Skala Konsep Diri untuk Mahasiswa Indonesia. Psikologi Universitas Diponegoro Vol 3, 2. 